\author{
Dr. Tone Jagodic, \\ Advisor to the President, European Olympic Committee \\ Dr. Zlatko Mateša, \\ President of the Croatian Olympic Committee
}

\title{
SOME ASPECTS OF LEGAL REGULATION OF SPORTS MARKETING
}

\author{
UDK: 796.078 \\ DOI: $10.31141 /$ zrpfs.2021.58.139.1 \\ Izvorni znanstveni rad \\ Primljeno: 20. rujna 2020.
}

There are different marketing activities generating money for sport subjects depending on their properties which are offered for commercial exploitation. Marketing consists of different tools and ways how to generate money for sport such as selling of broadcasting (TV) and media rights, sponsorship, merchandising, licensing, ticketing, charities, donations, patronages. From the legal point of view, it is interesting to explore how different marketing tools are regulated.

Certain parts of marketing matters are covered by legal rules. In 2011 Commission on Marketing and Advertising of the International Chamber of Commerce (ICC) issued the latest version of the ICC International Advertising and Marketing Communication Code. The document applies to different forms of sponsorship relating to corporate image, brands, products, activities or events of any kind. It includes sponsorship by both commercial and non-commercial organizations. The basic connection represents association between sports property and sponsor brand as a tool how to transfer image of the sport to the sponsor. The nature of the Code implies good governance in the field of sponsorship. Special attention deserves the principle of respecting the sponsorship property. The Code represents a useful opportunity for companies, business, associations, courts of law, public authorities, self regulatory bodies on national and international level and other institutions which are supposed to solve disputes in sponsorship cases.

European Union law together with national legislation of EU members have set up rules for advertising sector of TV broadcast. Television without Frontiers Broadcasting Directive consists with the detailed time and other limitations for different situations. As EU directive does not regulate visual coverage of sponsor logos and other insignia visible during sport competition on TV that means that sponsors and other subjects do not need to respect rules of the directive.

In the absence of formal legislation on national and international level the ICC Code represent a very useful tool to handle sponsorship agreements and possible disputes which could arise from them. The Code is designed primarily as an instrument for self-discipline. On the other hand it is also intended for use as an interpretative aid for the parties in the clarification of uncertainties arising under the sponsorship, as well as a reference for courts or arbitrators in sponsorship disputes.

Key words: marketing, marketing rules, ICC Code, eu law 


\section{INTRODUCTION}

The importance of sport marketing is increasing enormously and has become the mayor source of income for sport on international and national level. There are different marketing activities generating money for sport subjects depending on their properties which are offered for commercial exploitation. The value of property of subjects in sport is tightly connected with commercial status of particular sport activity with media being the most important factor of positioning certain sport in this evaluation. The globalization of the world economy and the intense competition, require the international business community to adopt standard rules. The adoption of these self-disciplinary rules is the best way that business leaders have to demonstrate that they are motivated by a sense of social responsibility, particularly in light of increased market liberalization and the emergence of new media and forms of marketing. Marketing consists of different tools and ways how to generate money for sport such as selling of broadcasting (TV) and media rights, sponsorship, merchandising, licensing, ticketing, charities, donations, patronages etc. As sponsorship contract represents the most important legal instrument for sport organizations, which are not in a position to sell their TV rights, the emphasis of this article is focused on sponsorship.

Law, like politics, has accompanied sports competitions throughout history, and the law often has had a unique status. ${ }^{1}$ Every legal order tends to protect rights which are regulated by rules of specific legal areas where they are domiciled. Right of personality represents legal ground of protection when image of an individual athlete is marketed. In case of trade marks of sport organizations it is obvious that rules of industrial property should be respected. It is therefore very important how to legally protect property of sport subjects which is commercially exploited. The status of legal protection is very different, depending on nature of legislation and stage of development of autonomous legal rules.

\section{SPONSORSHIP}

Sponsorship has become one of the major sources of funding for both local and international events involving sports, arts, environment, media, humanitarian and community projects, education and various other fields. Sponsorship benefits the general public by making possible the staging or broadcasting of events and activities which might not have been feasible otherwise and adding additional benefits to existing events and activities. Successful sponsorship therefore benefits

1 See more in Nafziger in chapter »International sports law « in Handbook on International Sports Law, edited by Nafziger and Ross, Edvard Elgar Publishing Limited, Cheltenham, U.K., 2011. 
all the concerned parties, including sponsors, organizers, media, performers, spectators and the general public. ${ }^{2}$

Sponsorship is an important marketing tool for companies and organizations to convey a broad message through association with the sponsorship property (e.g. event, activity, organization, individual, media or location). Sponsorship is an integral part of marketing strategy, but differs from other forms of commercial communications as well as from donations and patronage with respect to objectives, message and control. It can be undertaken as a single marketing activity, but will often utilize other marketing skills such as advertising, public relations and promotion in order to leverage the sponsorship and increase the impact.

\subsection{ICC International Advertising and Marketing Communication Code}

There is no formal legislation covering sponsorship on national level in the shape of contract regulated by special law. Courts and other institutions have to take into account legal rules from the field of civil, patent, industrial property, intellectual property, business, tort, tax, contractual, labor marketing and other different sectors of law. In 2011 Commission on Marketing and Advertising of International Chamber of Commerce issued the latest version of the ICC International Advertising and Marketing Communication Code. ${ }^{3}$ The Code follows the well-established ICC policy of promoting high standards of ethics in marketing via self-regulatory codes intended to complement the existing framework of national and international law. ${ }^{4}$

\subsection{The importance and scope of the Code}

The Code applies to all forms of sponsorship relating to corporate image, brands, products, activities or events of any kind. It includes sponsorship by both commercial and non-commercial organizations. It does not apply to product placement, nor to funding which lacks a commercial or communication purpose, such as donations or patronage, except where any of the aforesaid has a sponsorship element. The Code should be read in conjunction with the other ICC Codes, which regulate advertising practice, advertising and marketing on the internet, marketing and social research practice, environmental advertising, direct marketing, direct selling and sales promotion.

2 See also Jagodic, Pravne značilnosti sponzorskih pogodb v olimpijskem gibanju, (Legal characteristics of sponsorship contracts in the Olympic movement), doctoral thesis, Pravna fakulteta $\mathrm{V}$ Ljubljani, Slovenia, 2007.

3 https://cms.iccwbo.org/content/uploads/sites/3/2018/09/icc-advertising-and-marketingcommunications-code-int.pdf

4 The Code, which was first issued in 1992, is an expression of the business community's recognition of its social responsibilities in respect of marketing activities and communications. The new existing version was published in 2011 and is valid from 1 august 2011 on. 
The Code includes definitions of certain key terms such as sponsorship, sponsor, sponsored party, audience, media sponsorship, donations, patronage and product placement. The definition of sponsorship is a complex one and reflects the most important elements. As sponsorship can be regarded any commercial agreement by which a sponsor, for the mutual benefit of the sponsor and sponsored party, contractually provides financing or other support in order to establish an association between the sponsor's image, brands or products and a sponsorship property in return for rights to promote this association and/or for the granting of certain agreed direct or indirect benefits. After analyzing different parts of above definition we can put the most important elements into following scheme ${ }^{5}$ :

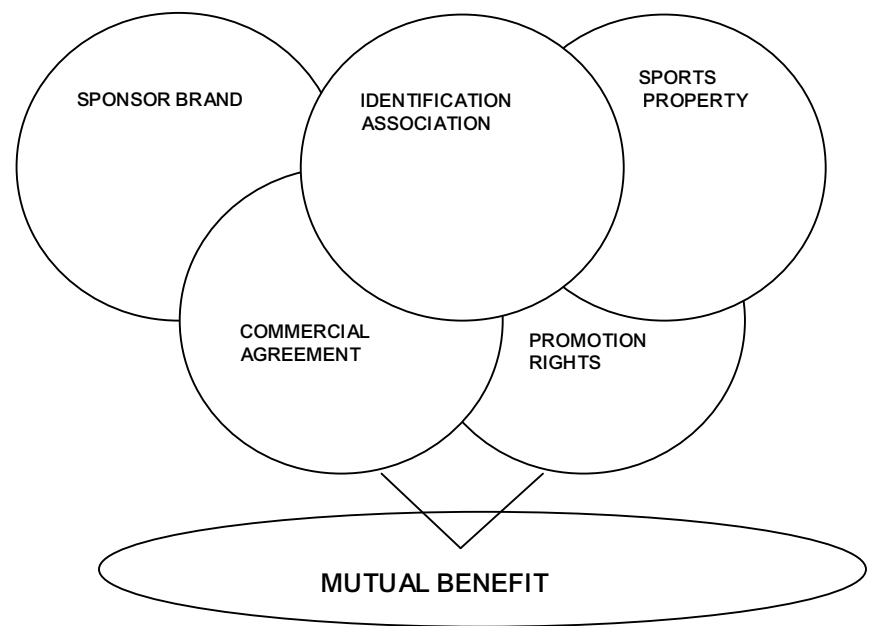

The basic connection represents association between sports property and sponsor brand as a tool how to transfer image of the sport to the sponsor. It is of course necessary to establish a commercial agreement with the possibility to promote that connection (identification in the awareness of the public). Both parties look forward for common - mutual benefit. Promotion of sponsorship in media by a sponsor can lift the value of sponsorship property and that is also the main objective and interest of both parties. ${ }^{6}$

Media exposure is of the vital importance, as it provides public identification of the connection between sponsor and sponsored party. Both parties try to achieve public awareness of close connection between them. Comparing with some other contracts it is very unique that common (mutual) interest of both parties is so

5 We should note that using Olympic rings does not mean any kind of misuse of the protected intellectual IOC property or even any kind of ambush activity. It is only a simple attempt to put elements into a scheme which represents logical connections among different parameters of sponsorship and can be easily remembered. It is useful for all kinds of sponsorship and not only for Olympic sponsorship.

6 See also Jagodic, Bednarik; Structural elements and definition of a sponsorship contract in sport, Kineosologija Slovenica, nr. 22, 1, p. 5-15., Faculty for sport, Ljubljana, Slovenia, 2016. 
essential. The common aim of both parties is to increase the value of the sponsorship property and they work together to achieve this common task. ${ }^{7}$ The aim of the sponsor is to take advantage of the goodwill associated with the particular sporting property that is being sponsored. ${ }^{8}$

The Code sets standards of ethical conduct to be followed by all concerned with sponsorship, whether as sponsors, sponsored parties, organizers, practitioners or agencies, or media, and is to be applied against the background of the applicable law. The Code is to be applied in good spirit, bearing in mind the characteristics of different kinds of sponsorship and the varying degrees of knowledge, experience and discriminatory ability of those to whom they are directed. It consists of basic principles, recommended behavior, restrictions and prohibitions.

\subsection{Basic principles}

All sponsorship should be legal, decent, honest and truthful. It should be conceived with a due sense of social responsibility and should conform to the principles of fair competition as generally accepted in business. The sponsorship should be based on contractual obligations between the sponsor and the sponsored party. Also, sponsors and sponsored parties should set out clear terms and conditions with all other partners involved to define their expectations regarding all aspects of the sponsorship deal.

It should be recognized that the sponsored parties have absolute right to decide on the value of the sponsorship rights that they are offering and the appropriateness of the sponsor with whom they contract. On the other hand donations and patronage are forms of altruism where money or goods may be given, for which there may be limited or no benefits, recognition or commercial return.

The Code clearly defends the autonomy of sponsored party what can be regarded as a notice of a weak position of sport subject in the contract. The Article B2 of the Code therefore claims that sponsorship should respect the autonomy and selfdetermination of the sponsored party in the management of its own activities and properties, provided the sponsored party fulfils the objectives set out in the sponsorship agreement.

When environmental advertising claims are made with respect to the sponsorship, the advertisements should conform to the principles set out in the Chapter of Social and Environmental Advertising. ${ }^{9}$ Both sponsors and sponsored parties should take into consideration the potential social or environmental impact of the sponsorship when planning, organizing and carrying out the sponsorship. Any sponsorship message fully or partially based on a positive (or reduced negative) social and

7 See also Jagodic, Sponsorship agreement as a formal legal instrument of modern sport, Pandektis, Vol 7, issues 1-2, 2007 p 41-47.

8 Verow, Lawrence, McCormick, Sport bussiness and the law, Jordans, 1999, p 204.

9 Article B9 of the Code 
environmental impact should be substantiated in terms of actual benefits to be obtained. Parties to the sponsorship should respect the principles set out in the ICC Business Charter for Sustainable Development.

\subsection{Prohibitions}

Sponsors and sponsored parties, as well as other parties involved in a given sponsorship, should avoid imitation of the representation of other sponsorships where such imitation might mislead or generate confusion, even if applied to noncompetitive products, companies or events. The sponsored party should never obscure, deform or impugn the image or trademarks of the sponsor or jeopardize the goodwill or public esteem associated with them. ${ }^{10}$

Code is setting the definition of ambushing of sponsored properties. No party should seek to give the impression that it is a sponsor of any event or of media coverage of an event, whether sponsored or not, if it is not in fact an official sponsor of the property or of media coverage. ${ }^{11}$

Sponsorship should never be operated in such a way as to endanger artistic or historical objects. Sponsorship which aims to safeguard, restore, or maintain cultural, artistic or historical properties or their diffusion, should respect the public interest related thereto. ${ }^{12}$

No sponsor, sponsored party or others involved should be party to the implementation of any sponsorship that they know to have been found unacceptable by the relevant self-regulatory body. This underlines the respect of self regulatory decisions.

\subsection{Recommended behavior}

The nature of the Code implies good governance in the field of sponsorship. Special attention deserves the principle of respecting the sponsorship property. The sponsor should take particular care to safeguard the inherent artistic, cultural, sporting or other content of the sponsorship property and should avoid any abuse of its position which would damage the identity, dignity, or reputations of the sponsored party or the sponsorship property. ${ }^{13}$

The audience should be clearly informed of the existence of a sponsorship with respect to a particular event, activity, programme or person and the sponsor's own message should not be likely to cause offence. Due note should be taken of existing professional ethics of the sponsored party.

\footnotetext{
10 Article B5

11 Article B4

12 Article B9

13 Article B5
} 
As we face the problem of different sponsored parties offering their properties for commercial exploitation to business partners, the code offers a good solution under the term of "multiple sponsorship". Where the activity or event requires or allows several sponsors, the individual contracts and agreements should clearly set out the respective rights, limits and obligations of each sponsor including but not limited to details of any exclusivity. In particular, each member of a group of sponsors should respect the defined sponsorship fields and the allotted communication tasks, abstaining any interference that might unfairly alter the balance between the contributions of the various sponsor. The sponsored party should inform any possible future sponsors of any sponsors already a party to the sponsorship. The sponsored party should not accept a new sponsor without ensuring that it does not conflict with any rights of sponsors who are already contracted and where appropriate, informing the existing sponsors. ${ }^{14}$

In this context media sponsorship is represented /article B12/ as a very special form of sponsorship with a clear distinction from sponsorship of sport subjects. Sponsorship of a media property (e.g. television or radio broadcast, publication, cinema, internet, mobile or other telecommunication technology) should not be unduly influenced by the sponsor so as to abrogate the responsibility, autonomy or editorial independence of the broadcaster, programme producer or media owner except to the extent where the sponsor is permitted by the applicable legislation to be the programme producer or co-producer, media owner or financier. Sponsored media properties should be identified as such by display of the sponsor's name and/ or logo at the beginning, during and/or end of the programme content. Particular care should be taken to ensure that there is no confusion between sponsorship of an event or activity and the media sponsorship of that event, especially where different sponsors are involved.

The Code sets the principle of responsibility. As sponsorship is conceptually based on a contract of mutual benefit, the onus for observing the code falls on the sponsor as well as the sponsored party, who between them have the ultimate responsibility for all aspects of the sponsorship, whatever its kind or content. Anyone taking part in the planning, creation or execution of any sponsorship has a degree of responsibility for ensuring the observance of the Code towards those affected or likely to be affected by the sponsorship. ${ }^{15}$

\subsection{The use of the Code}

The role of ICC is also underlined with the provision that the Code is to be applied nationally and internationally, and should be the basis for the decisions by bodies set up for the purpose of self-regulation. Any request for interpretation of the principles contained in the Code should be submitted to the ICC Code Interpretation

14 Article B11

15 Article B13 
Panel. The composition and appointment, competences, requests for interpretation, procedure, decisions and other elements which determines the role of Interpretation Panel is described in Annex 1.

In the absence of other similar rules of autonomous law it is obvious that the Code represents a useful opportunity for companies, business, associations, courts of law, public authorities, self regulatory bodies on national and international level and other institutions which are supposed to solve disputes in sponsorship cases.

\section{SELLING OF TV RIGHTS}

The importance of media has grown together with the organization of mayor international sport competitions. Olympic Games, World and Continental championship in Olympic sports and other attractive sports competition are commercially exploited by selling their broadcasting rights. The income of selling of TV rights have in last 10 years increased enormously and became the most important source of income for the organizers of these competitions. The organizer of sport competition is the owner of TV rights, which could be sold to broadcasting company, which is in principle entitled to broadcast sport competition on TV and to sell advertising time during the transmission of sport competition to advertisers. A broadcasting company has also the right to sell the right of transmission further to other broadcasting stations or companies and other new media online channels.

It is therefore importation to diverse (a) rights which represent the core of sponsorship and (b) TV rights, which both belong to the same sport organization. In commercial sense the »visibility « of sponsors during TV transmission of sport competition is very important from the standpoint of a sponsor, organizer and broadcaster. The ambition of a sponsor is that its logo could be seen on TV during sport competition and that is why such an element is an essential part of sponsorship agreement with the organizer. On the other hand the organizer has to ensure in the agreement with broadcasting company that the sponsor logo will be visible during TV transmission although broadcasting company is not in a relation with the sponsor of the organizer. The extent to which the event is commercially exploited is also important. The more visible the sponsors are in the production, the less TV networks are willing to pay. The TV broadcast will serve as a vehicle for the sponsors; the environment offered to traditional advertisers will be used by the sponsors... which are one of the reasons why IOC limits sponsor visibility on the site of the event. ${ }^{16}$ It is well known that Olympic Games is the only major international sports competition where venue advertising is not permitted and where athletes are not allowed to wear sports clothes with logos of sponsors.

The decision of selling TV right is essential from different angles. The organizer is entitled to get sponsorship fee from the sponsor and a payment from a broadcasting company. If a logo of a sponsor is visible during TV transmission the value of

16 Fischer, International Sponsorship, Symbiose Publishing, Montreal 1995, pp 50. 
sponsorship increases. The interest of sport organization is also connected with broadcasting of a particular sport on TV as it increases popularity of that sport and raises commercial value of the sport for further exploitation. General audience also has the interest to follow popular sport competition on TV and this is the reason that advertisers buy commercials during the TV transmission of the sports event.

Sponsorship and selling of TV rights both represent important marketing tools for sport organization. Commercial companies have to decide either for sponsorship with the organizer or for the offer from the broadcasting company for advertising during breaks of sport competition. Many times they decide to combine both possibilities which is the best way to get publicity during sport competition. Fisher ${ }^{17}$ points out the danger of evolution of TV for the development of sponsorship. It is always more reassuring for an advertiser to buy conventional advertising time on a TV network than to commit to portion of a budget to a sponsorship. New worldwide TV networks might thus represent a threat to international sponsorship.

\subsection{Legal regulation of $\mathrm{TV}$ advertising in $\mathrm{EU}$}

European Unity Law together with national legislation of EU members have set up certain rules which must be followed in advertising sector of TV broadcast. ${ }^{18}$ Sport sector is regulated by Television without Frontiers Broadcasting Directive with the detailed time and other limitations for different situations. Directive 2007/65/EC of the European Parliament and of the Council of 11 December 2007 amending Council Directive 89/552/EC on the coordination of certain provisions laid down the law, regulation or administrative action in Member States concerning the pursuit of television broadcasting activities. The Directive establishes the principle that Member States must ensure freedom of reception and that they may not restrict retransmission on their territory of television programmes from other Member States. ${ }^{19}$

Regarding the television advertising and sponsorship the provisions on advertising relate to:

- duration: $15 \%$ maximum of daily transmission time, $20 \%$ maximum within a given one-hour period;

- procedures for interrupting programmes;

- ethical considerations (in particular the protection of minors);

- compliance with certain criteria concerning advertisements for alcoholic beverages.

Advertising of tobacco and prescription medicines is prohibited.

17 Fisher, pp 52.

18 See also Watson, Graham, chapter European regulation of media rights, Handbook on International Sports Law, edited by Nafziger and Ross, Edvard Elgar Publishing Limited, Cheltenham, U.K.

19 https://eur-lex.europa.eu/legal-content/EN/ALL/?uri=LEGISSUM:124101. 
Sponsorship of television programmes is permitted, provided it complies with certain rules. The sponsorship must not affect the broadcaster's editorial independence. In addition, sponsored television programmes must not encourage the purchase of the sponsor's products or services. News and current affairs programmes may not be sponsored.

In other words it means that an advertiser has to obey rules governing "television advertising." On the other hand a position of visually presented logo of a sponsor during sport competition is completely different. Legal rules of advertising do not regulate signs of sponsorship visible during sport competition, what was clearly underlined also by European Court of Justice. In the case Bacardi France SAS against Television francaise 1SA (TF1), Groupe Jean - Claude Darmont SA and Girosport SARL ${ }^{20}$ on the interpretation of the Council Directive 89/552/CEE it was decided that advertising resulting from hoardings visible on screen during the retransmission of sporting events can not be regarded as television advertising defined by Directive 89/552.

\subsection{Benefits of sponsorship compared with effects of common advertising on $\mathrm{TV}$}

Commercial companies try to optimize their investment in sport and they have different possibilities how to manage this task. Funds for marketing, advertising and sponsoring are often from the same origin. As revenues from sponsorship represent very important income for majority for athletes and sport organizations it is vital to analyze differences of both activities and to be able to promote advantages of sponsorship.

Visual coverage of sponsor logos and other insignia through TV is not covered by the rules of regular TV advertising. As it does nor represents a method of advertising and is not regulated under strict rules of advertising it becomes very interesting for companies, which depend on advertising activities to become sponsors. Effect of visual presence of a sponsor sign is much more effective than classical advertising what make sponsors more interested to concentrate on prime time sport event sponsoring. Apart from that sponsor does not need to pay for its presence on TV to broadcasting company but to the sponsored subject only and such kind of promotion has no limits which are set for regular advertising. The task of sport subjects is to show this advantage to companies and their advertising or marketing agencies to become sponsors. The mission of sport law is to make sure that sponsorship through visual presence of sport subjects on TV represents an activity which is different from TV advertising and does not fall under the rules of advertising. It is then up to marketing to show economical advantages of such kind of sponsorship in relation to classical methods of advertising.

\footnotetext{
20 C 429/02 of ECJ, Bacardi France SAS v Television francaise 1 SA /TF1/ and Others, 2004.
} 


\section{LEGAL PROTECTION OF CERTAIN TRADE MARKS AND COMPETITIONS}

The case of legal protection of Olympic symbol as an example of trademark of sport organization is an act of international law. IOC original right of use of Olympic image has its background in Nairoby treaty of protection of Olympic symbol. ${ }^{21}$ All states which ratify Nairoby treaty are obliged to ensure the proper use of Olympic Symbol as a mark or other sign for commercial purposes. In this case a single individual legal act is protecting a particular right of industrial property (symbol of Olympic rings). ${ }^{22}$ Many National Olympic Committees had also legally protected their registered symbols, words, and other verbal or visual signs within their own national territory. ${ }^{23}$

The organizers of mayor international competitions (Olympic Games, FIFA World Cups, UEFA European Championships, etc.) try to legally protect their trade marks on the territory where the competition takes place. A special law is introduced a few years before the competition and expires when the competition is over. This kind of law is not of permanent validity as it is intended to act only for particular competition. Legal protection of mentioned trade marks is valid for all possible commercial exploitation including sponsorship, selling of TV rights, merchandising, licensing and others.

\section{OTHER MARKETING TOOLS}

Apart from sponsorship agreements there are some other modern marketing tools which are used frequently in the direction of getting funds from commercial partners. One of very frequent legal mechanisms is an endorsement as a promotional and marketing tool that takes the advantage of a personality's reputation. In the context of sport the endorsement usually makes an obvious association between the sportsman and the tools of trade..$^{24}$ An endorsement agreement is an agreement for the right of a sponsoring company to use personality's service and the right to use their name and likeness in an agreed manner. It is the personal recommendation by personality of a product or service and there is usually an obligation of some sort for the personality to wear and use the product or service being endorsed. On the other hand the sponsoring company will advertise their relationship with the personality. An endorsement is sometimes regarded to be only a particular form of sponsorship but a proper look at the structure and nature of endorsement more deeply confirms

$21 »$ Nairoby treaty on the protection of the Olympic symbol«, was issued on 26.9.1981 in Nairoby; see web page https://wipolex.wipo.int/en/text/287413.

22 Nairoby treaty only covers the use of Olympic rings as an Olympic symbol what means that name, word(s) and other written expressions of term Olympic are not protected by the treaty.

23 Like »Olympic Sybmol Protection Act« (Great Britain), »Amateur Sports Act« (USA), »Bundesgesetz zum Schutz der Olympischen Embleme und Bezeihnungen« (Austria) and many others.

24 Verow, Lawrence, McCormics, Sport bussiness and the law, Jordans, p 235. 
that it is a special marketing tool, which in certain ways differs from sponsorship. There are different ways how to legally protect the rights in endorsement agreements and they mainly relate to intellectual property rights. In UK endorsements cold be protected by legal rules of trade marks, passing off, copyright, defamation and malicious falsehood, advertising standards and trade descriptions. ${ }^{25}$

Licensing occurs when permission is given to a third party to associate the sport subject with one of the products or services. The license is usually directly between the owner of the rights and the licensee. Selling merchandise is an example of licensing and merchandising agreement usually takes the form of a license of intellectual property rights. Merchandising of sport articles is regulated by legislation on international and national level. Ticketing represents another marketing tool for those sport organizations which organize sports events. Each of these marketing segments should be analysed separately and exceeds the context of this paper.

\section{SPONSORSHIP AND DONATION}

It is always worth to have in mind a distinction between sponsorship and donation ${ }^{26}$. In case if the difference is not clear it might become a problem for parties involved when a tax authority controls the transactions.

Formally a donation is a contract whereby one person (the donor) undertakes to transfer to the other person (the recipient) free of charge ownership or other right or otherwise enrich the recipient with the property, and the recipient declares to agree. It is a bilateral legal transaction that is unilaterally binding and for the recipient free of charge. An important element is the position of the donor and its wish to help the recipient. Usually it expresses donor's motive, inclination and its free will for donation which in is many cases also connected with the charity.

This means that the donor can also contribute funds to the sport associations up to certain amount which differs from county to county. ${ }^{27}$ This amount is deducted from the tax base, which is supposed to give an incentive to the donors to support the associations. Usually there are two conditions for the donation to be recognized as a tax deductible expense. In accordance with the law the recipient must be registered for performing certain sport activities, and the donation must not exceed certain amount of the total income of the donor which depends on national legislation.

Where sports subject gets sponsorship or some other form of support it makes taxable supplies if, in return, sports subject obliged to provide the sponsor with a significant benefit. The sponsorship contract with the sponsor normally requires sports subject to do something in return. On the other hand sport subject can receive financial or other support in the form of a donation or a gift. As long as donor

25 Verow, Lawrence, McCormics, Sport bussiness and the law, Jordans, p 234-237.

26 The same principles as for donation are also valid for charity and patronage.

27 The EU does not have a direct role in collecting taxes or setting tax rates. The amount of tax each citizen pays is decided by their national government, along with how the collected taxes are spent. 
participation is freely given and secure nothing in return for the donor the amount is outside the scope of VAT as a taxable supply is not created. For the donation the company (donor) can claim a tax deduction. When a company makes a donation, it is the company that claims the relief. There is no grossing up arrangement in this case. The tax position of the sport subject depends on the system of their VAT registration which differs from county to county.

\section{CONCLUSION}

Rights of sport subjects are regulated by rules of the field of law there they are domiciled. Formal legislation is recognized as appropriate framework for practical use in different forms of commercial communications of sport marketing, when the right of sport subject falls into a certain category of law. It is obvious that only some parts of marketing issues are covered by certain laws. These legal instruments are based on principles that are not primarily sport-oriented but cover another sphere, such as trade marks, intellectual rights, merchandising or advertising. As an example the EU Directive and following national legislation of different EU countries aims to defend TV audience from extensive advertising. EU directive does not regulate visual coverage of sponsor logos and other insignia visible during sport competition on TV what means sponsors and other subjects do not need to respect rules of the directive.

In the absence of formal legislation on national and international level the ICC Code represent a very useful tool to handle sponsorship agreements and possible disputes which could arise from them. The Code is designed primarily as an instrument for self-discipline. On the other hand it is also intended for use as an interpretative aid for the parties in the clarification of uncertainties arising under the sponsorship, as well as a reference for courts or arbitrators in sponsorship disputes. ICC expects that the Code will promote adherence to high standards of sponsorship practice, leading to significant benefits for all concerned as well as for society as a whole. It could be concluded that autonomy of sport is deeply reflected in autonomous legal infrastructure which makes the basic legal core for sport marketing. 


\section{NEKI ASPEKTI PRAVNE REGULACIJE SPORTSKOG MARKETINGA}

Postoje različite marketinške aktivnosti koje generiraju novac za sportske subjekte, ovisno o njihovim svojstvima koja se nude u komercijalne svrhe. Marketing se sastoji od različitih alata i načina kako generirati novac za sport, poput prodaje radiodifuznih programa (TV) i medijskih prava, sponzorstva, prodaje robe, licenciranja, prodaje ulaznica, dobrotvornih organizacija, donacija, pokroviteljstva. S pravnog gledišta, zanimljivo je istražiti kako su regulirani različiti marketinški alati.

Određeni dijelovi marketinških pitanja obuhvaćeni su zakonskim pravilima. 2011. Komisija za marketing i oglašavanje Međunarodne trgovačke komore (ICC) izdala je najnoviju verziju Međunarodnog kodeksa oglašavanja i marketinške komunikacije ICC-a. Dokument se odnosi na različite oblike sponzorstva koji se odnose na korporativni imidž, robne marke, proizvode, aktivnosti ili događaje bilo koje vrste. Uključuje sponzorstvo i komercijalnih i nekomercijalnih organizacija Osnovna veza predstavlja povezanost između sportske imovine i marke sponzora kao alata za prijenos slike sporta na sponzora. Priroda Kodeksa podrazumijeva dobro upravljanje na polju sponzorstva. Posebna pažnja zaslužuje načelo poštivanja sponzorske imovine. Kodeks predstavlja korisnu priliku za tvrtke, tvrtke, udruge, sudove, javne vlasti, samoupravna tijela na nacionalnoj i međunarodnoj razini te druge institucije koje bi trebale rješavati sporove u sponzorskim slučajevima.

Pravom Europske unije, zajedno s nacionalnim zakonodavstvom članica EU, postavljena su pravila za sektor oglašavanja TV emisija. Direktiva o televiziji bez graničnog prijenosa sastoji se od detaljnih vremenskih i drugih ograničenja za različite situacije. Kako direktiva EU ne regulira vizualno pokrivanje logotipa sponzora i drugih obilježja vidljivih tijekom sportskog natjecanja na TV-u, to znači da sponzori i drugi subjekti ne trebaju poštivati pravila te direktive.

U nedostatku formalnog zakonodavstva na nacionalnoj i međunarodnoj razini, pravila ICC predstavljaju vrlo korisno sredstvo za rješavanje sponzorskih sporazuma i mogućih sporova koji bi iz njih mogli proizaći. Kodeks je zamišljen prvenstveno kao instrument samodiscipline. S druge strane, također je namijenjen korištenju kao pomoć u tumačenju strana u razjašnjavanju nesigurnosti koje nastaju pod sponzorstvom, kao i referenca za sudove ili arbitre u sporovima o sponzorstvu.

Ključne riječi: marketing, marketinška pravila, ICC kodeks, EU pravo 